\section{EL FINAL DEL SILENCIO: DICTADURA, SOCIEDAD Y DERECHOS HUMANOS EN \\ LA TRANSICIÓN: ARGENTINA, 1979-1983}

de Marina Franco,

Buenos Aires, Fondo de Cultura Económica,

2018, 411 pp.

GABRIELA QUIRITI

Centro de Estudios Históricos, Universidad Nacional de Mar del Plata (Argentina).

e-mail: gabyquiriti@gmail.com

Los debates sobre la llamada transición a la democracia en Argentina han ocupado, con matices, un lugar de importancia en la historiografía desde la década del 80 hasta la actualidad. Sin dudas ha primado una visión lineal en la cual la democracia aparece como punto de llegada y se ignora la persistencia de imaginarios y prácticas propias del período dictatorial. Marina Franco, investigadora de conicet y docente del Instituto de Altos Estudios Sociales de la Universidad de San Martín, ha tratado estas temáticas con anterioridad en algunos de sus libros de los cuales el último es justamente el objeto de esta reseña. En El final del silencio: dictadura, sociedad y derechos humanos en la transición: Argentina, 1979-1983, la autora desarrolla una serie de cuestionamientos a los lugares comunes sobre el proceso transicional. Con este fin, se sirve de un corpus centrado en la prensa de época, aunque incluye también testimonios orales. Dicho corpus es analizado de forma aguda para indagar en las cuestiones relativas al complejo período que Franco sitúa entre los años 1979 y 1983.

La obra se desarrolla a lo largo de cuatro capítulos ordenados cronológicamente, cada uno de los cuales aborda un momento distinto de la transición. El análisis lleva a la autora a problematizar la lectura tradicional de este proceso y los presupuestos que se han cristalizado en la memoria social en las últimas décadas. Es decir, se pone en cuestión la idea según la cual el derrumbe del autoproclamado Proceso de Reorganización Nacional se dio exclusivamente a partir del fracaso de guerra de Malvinas y, en ese contexto, la cuestión de los derechos humanos fue central en la deslegitimación. Franco busca oponer una visión más compleja, respondiendo a algunas preguntas funda- 
mentales: ¿cómo construyó la sociedad su vínculo con la represión y la violencia por parte del Estado? ¿Qué impacto tuvo el tema de los desaparecidos en la transición a la democracia? Evitando los anacronismos, la autora busca responder a estos interrogantes sin dejarse llevar por aquel relato memorial cimentado en la sociedad y tendiente a exagerar cuestiones hacia las cuales los argentinos solo volverían su mirada crítica con posterioridad.

El comienzo de la deslegitimación del régimen dictatorial es abordado en el primer capítulo y de forma constante a lo largo de la obra. En este sentido, Franco señala que la cuestión de los Derechos Humanos quedó relegada frente a la importancia que adquirían otros factores, principalmente los económicos y sociales, que traerán aparejadas las primeras fricciones. En una etapa inicial, la represión al llamado enemigo subversivo no era cuestionada, sino que incluso era celebrada por parte de algunos actores. Su análisis de la prensa de la época reviste importancia puesto que viene a derribar uno de los mitos consolidados sobre el Proceso: el de la sociedad inocente que no sabía lo que estaba pasando. El trabajo con dichas fuentes servirá a la autora para demostrar que había conocimiento y menciones en la prensa de la represión y que ella era aceptada por el grueso de la población, al punto de desprestigiar los informes internacionales como aquel presentado por la Comisión Interamericana de Derechos Humanos después de su visita en 1979. En consideración de ello, la gran pregunta que surge es cuándo la cuestión de los Derechos Humanos comenzó a ser parte de la agenda pública, duda que la autora busca resolver.

Sin dudas, a pesar de este panorama de aceptación general de la represión, era innegable ya desde fines de la década de I970 que en algún momento sus consecuencias deberían ser enfrentadas. Este es otro de los hilos de análisis que sigue se sigue en el libro: las diversas respuestas ensayadas sobre cómo cerrar el proceso represivo. Con respecto a este punto, los márgenes de maniobra se irán reduciendo, pasando de una primera etapa en la cual el Proceso era capaz de plantear un traspaso de poder a largo plazo, con límites para el disenso, a un final precipitado y ya sin ningún tipo de salvaguarda para sus intereses más que una autoamnistía efímera y poco promisoria. De cualquier manera, la investigación busca desmitificar la idea del juzgamiento generalizado por parte de la sociedad con respecto a la cuestión represiva ya que, al menos hasta principios de la década del 8o, la tarea llevada a cabo por las Fuerzas Armadas era reconocida y el cierre de esta etapa estaba ligado únicamente al olvido para poder seguir adelante.

En el segundo capítulo, se analiza el momento de ilusión de apertura, que coinci- 
de con el gobierno de Viola, y la búsqueda del cierre del Proceso. En este caso, se centra en las internas militares y la reactivación política que implicará a largo plazo el surgimiento de la Multipartidaria. Todo esto daría lugar al giro opositor cuyo entendimiento como inicio de la transición es cuestionado: Franco sostiene que 198I no fue un año de rotundos cambios; apenas habilitó instancias de diálogo en pos de una normalización que aparecía todavía como un horizonte lejano. El capítulo versa sobre la resistencia de la corporación militar a habilitar dicha normalización y el creciente rechazo que este endurecimiento de posiciones produjo, ligado al fracaso económico del régimen. Progresivamente, diversos actores como la Iglesia y la prensa se distanciaron del gobierno, incluso haciendo noticia de la represión por primera vez. Sin embargo, Franco matizará durante todo su estudio el impacto de lo que llama «la cuestión de los desaparecidos», escapando a ciertos sentidos de época que suelen imprimirse de forma anacrónica sobre los años del Proceso. Este asunto solo cobraba importancia fundamental en las negociaciones con respecto al cierre del pasado. En las restantes páginas del capítulo, la autora aborda de manera minuciosa el accionar de dos actores centrales con respecto a lo antedicho: los partidos políticos y el sistema judicial, destacando en todo momento su actitud ambigua y pragmática.
La Guerra de Malvinas tuvo como consecuencia una decidida eclosión antidictatorial que Franco trata a lo largo del tercer capítulo. El clima opositor se consolidó y la sociedad comenzó a demandar a los sectores castrenses una rendición de cuentas sobre aquellos asuntos espinosos para el régimen. En este período, el análisis está centrado en las constantes negativas militares a brindar respuestas satisfactorias a dichas exigencias y la preparación de su acto final de gobierno: la sanción de la autoamnistía que les permitiría asegurar la no revisión de los crímenes perpetrados. Esta preocupación da cuenta de que la gravedad del asunto era reconocida a medida que la gran mayoría de los actores sociales se sumaban a la defección, cuestionando por primera vez al régimen, aunque fuera en los términos de la que luego sería conocida como «teoría de los dos demonios». La respuesta castrense mediante la reafirmación de sus esquemas bélicos y el planteo de la supuesta continuidad del peligro subversivo es también objeto de análisis. En este sentido, la autora marca la publicación del Documento Final de la Junta Militar sobre la guerra contra la subversión, de carácter auto inculpatorio, como un punto de inflexión, rompiendo con otras interpretaciones que han tendido a soslayar su importancia.

La publicación del documento final resulta un clivaje particular, puesto que estrechó las opciones para la transición, 
marcando la falta de voluntad por parte de las fuerzas armadas de resolver la cuestión represiva y dejándola en manos del gobierno democrático que asumiera el poder. Este es el núcleo del contenido del capítulo cuarto de la obra, en el cual Franco brinda un panorama de la etapa final de la transición. En ella, los actores dominantes comenzaron a amenazar cada vez con más fuerza el poder militar y se produjo la recomposición política y sindical propia de la preparación para la normalización democrática. Sin embargo, el pragmatismo fue la marca esencial en el accionar de todos ellos, en especial para la cuestión de los derechos humanos. En este punto, el cuestionamiento estaba situado en los medios de la represión, para los cuales se reclamaba una vuelta a la legalidad que, según Franco, marca el final de un ciclo histórico. En las restantes páginas del capítulo, la autora se aboca a reconstruir el proceso de preparación y sanción de la ley de autoamnistía y la carrera electoral hacia octubre de 1983.

A modo de conclusión, debe destacarse que esta obra resulta una incómoda apreciación sobre el accionar de la socie- dad argentina en ese particular momento de la historia. Esto le aporta un valor innegable, puesto que lleva a cuestionar lugares comunes constituidos sobre la transición a la democracia. Franco señala que la construcción de una cultura de los derechos humanos fue un lento proceso que tuvo sus orígenes en el seno de la dictadura, pero que recién se cimentó en los primeros años de la recuperación democrática. Es destacable su intento por comprender, alejándose de los marcos memoriales presentes, la huella que había dejado en la sociedad el período de violencia política previo a la dictadura. En este sentido, resulta interesante su propuesta de análisis que parte de lo que podríamos llamar «la otra transición», aquella que se produjo entre 1973 y 1976 en contexto de la escalada de violencia y que determinó los marcos de sentido en los cuales sería comprendido por los contemporáneos el proceso represivo. La obra no defrauda su objetivo central que es, en última instancia, plantear una duda sobre cuál fue el rol que jugaron realmente la sociedad y los actores políticos en aquel final del silencio. 